\title{
Effect of Meteorological and Micrometeorological Parameters on Stripe Rust (Puccinia striformis f. sp. tritici) Severity of Wheat
}

\author{
Sarabjot Kaur Sandhu $^{1 *}$, L.K. Dhaliwal ${ }^{1}$ and P.P.S. Pannu ${ }^{2}$ \\ ${ }^{1}$ School of Climate Change and Agricultural Meteorology, PAU, Ludhiana, Punjab, India \\ ${ }^{2}$ Department of Plant Pathology, PAU, Ludhiana, Punjab, India \\ *Corresponding author
}

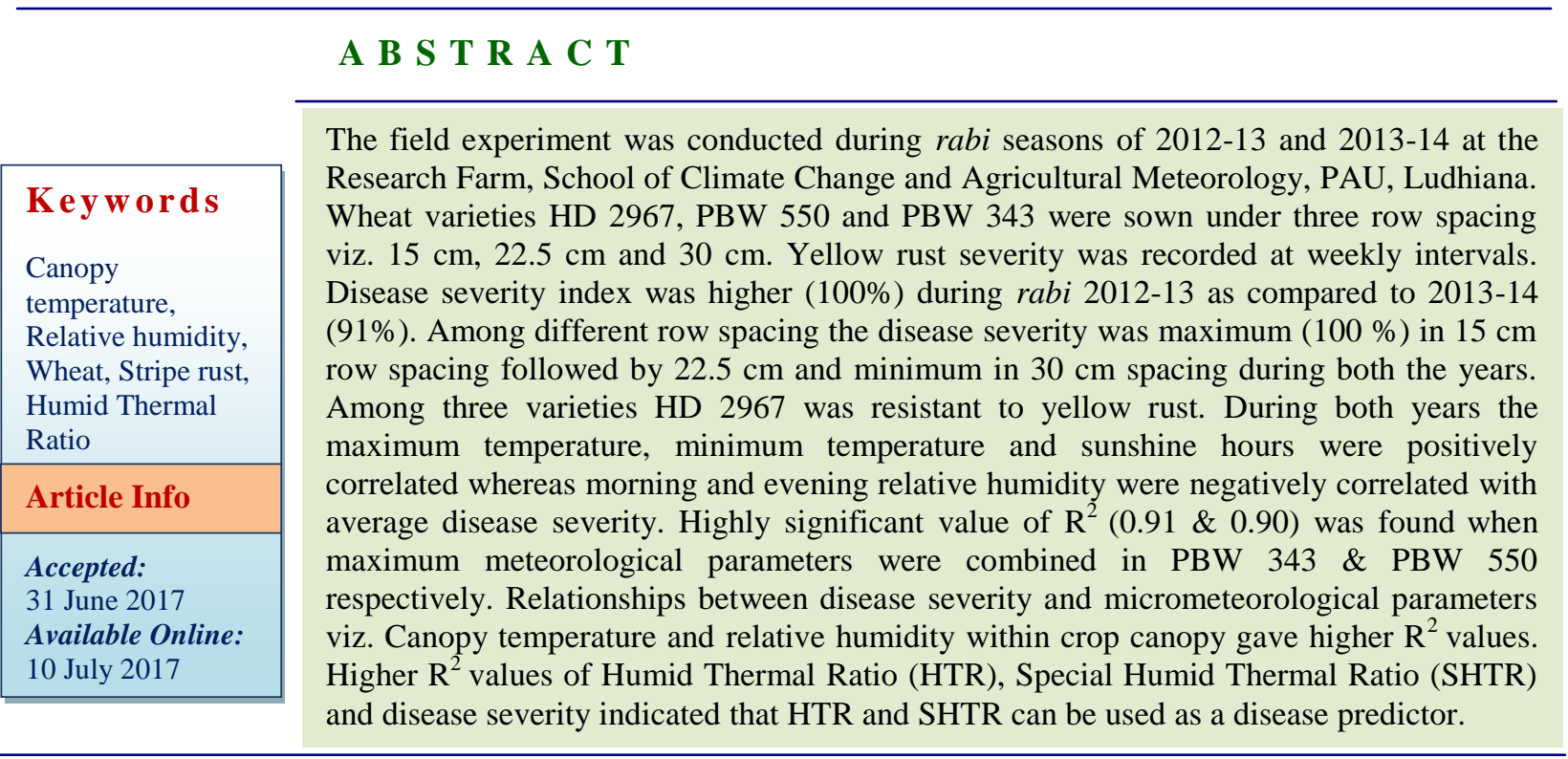

\section{Introduction}

Wheat is a major cereal crop of the world in terms of tonnage for human food security and is grown under wide environmental conditions. It covers 25.2 million hectares with 84.3 per cent area under irrigation. Wheat crop is attacked by large number of diseases and insects which often appear in epidemic proportions causing yield losses and deterioration in quality. Despite the increasing understanding of plant diseases, they remain a major constraint to wheat production. Periodic leaf rust epidemics have occurred in most decades of the last century, thus worldwide leaf rust is considered as important disease of wheat. With the current global situation requiring higher wheat production from declining land areas, more productive farming systems will potentially increase pressure from diseases such as stripe rust or yellow rust. Under the north-western plain zone which is major wheat producing area in the country, stripe rust caused by Puccinia striformis westend. $f$. sp. tritici is the major disease problem. The cool weather at night allows stripe rust to develop and the pathogen to survive. In North India, due to the favourable weather conditions for disease spread the area remain perpetually under the 
threat of this disease. Huerta-Espino et al., (2011) reported that Puccinia triticina has a wide virulence range and is broadly adapted to diverse climatic conditions, leading to regular and significant yield losses over large geographical areas. Severity of stripe rust is affected by different meteorological parameters and microclimate of crop. Microclimate modification can be useful in management of stripe rust as disease is highly influenced by microclimate of the crop. So keeping this in view, the experiments were conducted to study the effect of different meteorological parameters and microclimate on stripe rust severity.

\section{Materials and Methods}

Wheat varieties HD 2967, PBW 550 and PBW 343 were sown under three row spacing viz. $15 \mathrm{~cm}, 22.5 \mathrm{~cm}$ and $30 \mathrm{~cm}$ during rabi seasons of 2012-13 and 2013-14. The crop was raised as per recommendations of Punjab Agricultural University. Daily meteorological observations on temperature $\left({ }^{\circ} \mathrm{C}\right)$, relative humidity (\%), sunshine hours (hrs/day) and rainfall $(\mathrm{mm})$ were recorded at the Agro meteorological Observatory $\left(30^{\circ} 54^{\prime} \mathrm{N}\right.$, latitude and $74^{\circ} 48^{\prime} \mathrm{E}$ longitude and altitude of $247 \mathrm{~m}$ above the mean sea level) which is situated $150 \mathrm{~m}$ away from the experimental area. Microclimatic parameters viz. canopy temperature and relative humidity within crop canopy was recorded under different treatments. Canopy temperature was measured at 1400 hours at weekly interval with the help of Infrared Thermometer. The Infrared Thermometer was held at $45^{\circ}$ to the horizontal above the canopy so as to look in a downward direction towards the crop surface. The relative humidity was measured at 1400 hours at weekly interval with the help of Belfort Psychron.

Stripe rust severity was recorded visually as the percentage of leaf area infected according to the modified Cobb's or Peterson's scale (Peterson et al., 1948).The disease was recorded on 10 randomly selected plants and per cent plants affected by the disease were recorded at weekly intervals. Severity index was calculated by using the following formulae:

Area of plant tissue infected $\mathrm{x} 10$

Severity index $(\%)$ = ---------------------X 100

Total area of plant

Correlation coefficients and step wise multiple regression analysis was conducted between stripe rust disease severity index and different meteorological parameters like temperature, relative humidity, sunshine hours and rainfall (Table 2). Humid Thermal ratio (HTR) was calculated by using following formulae:

Humid Thermal Ratio (HTR)

Mean Relative humidity

Mean temperature

Relationships between disease severity and HTR, SHTR microclimatic parameters viz. Canopy temperature and relative humidity within crop canopy were developed.

\section{Results and Discussion}

\section{Disease severity}

Disease severity index was calculated on the basis of per cent disease severity observations. Disease severity index was higher (100\%) during rabi 2012-13 as compared to 2013-14 (91\%). Difference in disease severity during both years was not high as weather conditions during both the years did not vary much. Temperature and relative humidity were the key factors for stripe rust development. Among different varieties, due to varietal difference, variety HD 2967 was highly resistant to stripe rust whereas variety PBW 343 and PBW 550 were 
highly susceptible and susceptible to stripe rust respectively. During 2012-13 and 201314 , the disease severity was maximum in 15 $\mathrm{cm}$ row spacing $(100 \%, 95 \%)$ followed by $22.5 \mathrm{~cm}(100 \%, 91 \%)$ and minimum in $30 \mathrm{~cm}$ row spacing $(95 \%, 83 \%)$ in $\mathrm{PBW} 343$. In PBW 550 disease severity was $(100 \%$, 90\%) in $15 \mathrm{~cm}$ row spacing followed by $22.5 \mathrm{~cm}$ $(100 \%, 85 \%)$ and least in $30 \mathrm{~cm}(90 \%, 81 \%)$ as shown in figures 1, 2, 3 and 4 . The main reason for low disease severity in wider spacing was change in microclimate. As in narrow spacing relative humidity within canopy was higher $(86 \%)$ during early period of disease development as compared to wider spacing (80 \%). Crop sown under $15 \mathrm{~cm}$ spacing was very dense so disease spread was high under narrow spacing. Maximum temperature range was recorded between 15 to $32^{\circ} \mathrm{C}$. However, the maximum disease development was noticed in temperature range between 18 to $28^{\circ} \mathrm{C}$. When the maximum temperature reached above $28^{\circ} \mathrm{C}$, disease advancement became stagnant. Milus and Seyran (2004) reported that stripe rust caused by the new isolates tends to develop faster than the old isolates at relatively high temperatures. Temperatures above $28^{\circ} \mathrm{C}$ were detrimental to infection caused by rust pathogen (Marchetti et al., 1976).

\section{Disease severity and meteorological parameters}

Several environmental variables affect the production, dispersal and survival of uredinospores (Eversmeyer and Kramer 1995). The correlation coefficients were worked out between disease severity and meteorological parameters. The weekly meteorological parameters, viz., maximum temperature $\left(\mathrm{Tmx},{ }^{\circ} \mathrm{C}\right)$, minimum temperature (Tmn, ${ }^{\circ} \mathrm{C}$ ), morning relative humidity (RHm, $\%)$, evening relative humidity (RHe, \%) and sunshine hours (SSH, Hours/day) were correlated with weekly average disease severity for rabi 2012-13 and 2013-14 (Table
1). Average disease severity was calculated as mean of disease severity in three row spacing. Total rainfall did not show significant relationship with disease severity. During both the years the maximum temperature, minimum temperature and sunshine hours were positively correlated with the disease severity in different treatments.

Similar results were reported by Murray et al., (2005). Papastamati et al., (2007) also reported that the most important weather variable for the progress of stripe rust is temperature, followed by dew period and light quantity. The disease severity showed a negative correlation with morning and evening relative humidity. Similar results were reported by Lemaire et al., (2002).

The rainfall during the seasons did not show any significant correlation with disease incidence. Difference of rainfall during crop duration and disease severity was not very high but when rainfall of this period was plotted with average disease severity (Fig. 5). It was observed that during peak severity of disease $\left(5^{\text {th }} \mathrm{SMW}\right.$ to $\left.12^{\text {th }} \mathrm{SMW}\right)$ rainfall was more during 2012-13 as compared to 201314.

The high rainfall may have played significant role in disease spread as indicated in different studies. Pielaat et al., (1998) proposed a model to represent the special spread of spores by rain splash from a point source at any time during a rain event over a homogenous surface. The model was applicable for characterizing splash dispersal under range of conditions. Similarly, Srinivasan (1983) also developed regression models for the prediction of stripe rust in submountain and central plain regions of Punjab and he also reported that relative humidity and precipitation frequency were the major factors influencing the outbreak of this disease. 
The step-wise regression analysis was conducted to find the cumulative effect of different meteorological parameters on disease severity by taking disease severity as dependent variable and different meteorological parameters as independent variables. The multiple regression analysis between disease severity and meteorological parameters for different row spacing is shown in table 4 . The $\mathrm{R}^{2}$-value was 0.91 and 0.90 when all the meteorological parameters were combined in variety PBW 343 and PBW 550 under different treatments. This indicates that 90 and 91 percent variability in disease severity in PBW 550 and PBW 343 was because of different meteorological parameters. Similar regression models for predicting the stripe rust in central plain regions of Punjab were developed by Dutta $e t$ al., (2008). Rader et al., (2007) developed two models to predict the occurrence of leaf rust (caused by Puccinia recondita or $P$. triticina) using air temperature, relative humidity and precipitation.

Table.1 Correlation coefficients between average disease severity and Different meteorological parameters during rabi season 2012-13 and 2013-14

\begin{tabular}{|l|l|l|l|l|l|}
\hline \multicolumn{7}{|l|}{ Tmx } & Tmn & RHm & RHe & SSh \\
\hline 2012-13 & \multicolumn{5}{|l|}{} \\
\hline PBW 550 & $0.88^{*}$ & $0.92^{*}$ & $-0.52^{*}$ & $-0.59^{*}$ & $0.73^{*}$ \\
\hline PBW 343 & $0.90^{*}$ & $0.93^{*}$ & $-0.60^{*}$ & $-0.59^{*}$ & $0.74^{*}$ \\
\hline 2013-14 & l $^{*}$ & $0.84^{*}$ & $-0.80^{*}$ & $-0.73^{*}$ & $0.81^{*}$ \\
\hline PBW 550 & $0.91^{*}$ & $0.89^{*}$ & $-0.80^{*}$ & $-0.72^{*}$ & $0.80^{*}$ \\
\hline PBW 343 & $0.90^{*}$ & 0
\end{tabular}

*Significant at $5 \%$ level of significance

Table.2 Stepwise multiple regression analysis between average stripe rust disease severity (Y) and meteorological parameters (Pooled data 2012-13 and 2013-14)

\begin{tabular}{|l|l|}
\hline Regression Equation & $\mathrm{R}^{2}$ \\
\hline PBW 550 & \\
\hline $\mathrm{Y}=-60.5+1.27 \mathrm{Tm} x+8.47 \mathrm{Tmn}$ & 0.83 \\
\hline $\mathrm{Y}=-87.8-3.03 \mathrm{Tm} x+12.4 \mathrm{Tmn}+0.57 \mathrm{RHm}+0.01 \mathrm{RHe}-0.44 \mathrm{RF}+4.74 \mathrm{SSh}$ & 0.90 \\
\hline PBW 343 & \\
\hline $\mathrm{Y}=-56.7+1.51 \mathrm{Tm} x+7.80 \mathrm{Tmn}$ & 0.88 \\
\hline $\mathrm{Y}=-103.4-2.99 \mathrm{Tm} x+12.1 \mathrm{Tmn}+0.90 \mathrm{RHm}-0.15 \mathrm{RHe}-0.60 \mathrm{RF}+4.38 \mathrm{SSh}$ & 0.91 \\
\hline
\end{tabular}

Table.3 Relationship between stripe rust disease severity (Y) and Canopy temperature (pooled data PBW 550 and PBW 343)

\begin{tabular}{|l|l|l|}
\hline $2012-13$ & Regression Equation & $\mathrm{R}^{2}$ \\
\hline $15 \mathrm{~cm}$ & $\mathrm{Y}=-0.026 \mathrm{x}^{3}+1.765 \mathrm{x}^{2}-30.69 \mathrm{x}+159.3$ & 0.89 \\
\hline $22.5 \mathrm{~cm}$ & $\mathrm{Y}=-0.03 \mathrm{x}^{3}+1.993 \mathrm{x}^{2}-35.95 \mathrm{x}+189.7$ & 0.91 \\
\hline $30 \mathrm{~cm}$ & $\mathrm{Y}=-0.022 \mathrm{x}^{3}+1.554 \mathrm{x}^{2}-28.35 \mathrm{x}+150.2$ & 0.92 \\
\hline $2013-14$ & & \\
\hline $15 \mathrm{~cm}$ & $\mathrm{Y}=-0.020 \mathrm{x}^{3}+1.379 \mathrm{x}^{2}-23.67 \mathrm{x}+118.2$ & 0.91 \\
\hline $22.5 \mathrm{~cm}$ & $\mathrm{Y}=-0.031 \mathrm{x}^{3}+2.210 \mathrm{x}^{2}-43.52 \mathrm{x}+262.3$ & 0.88 \\
\hline $30 \mathrm{~cm}$ & $\mathrm{Y}=-0.013 \mathrm{x}^{3}+0.809 \mathrm{x}^{2}-10.29 \mathrm{x}+17.38$ & 0.89 \\
\hline
\end{tabular}


Table.4 Relationship between stripe rust disease severity (Y) and relative humidity within crop Canopy (pooled data PBW 550 and PBW 343)

\begin{tabular}{|l|l|l|}
\hline $2012-13$ & Regression Equation & $R^{2}$ \\
\hline $15 \mathrm{~cm}$ & $Y=0.007 \mathrm{x}^{3}-1.668 \mathrm{x}^{2}+115.7 \mathrm{x}-2482$ & 0.73 \\
\hline $22.5 \mathrm{~cm}$ & $\mathrm{Y}=0.023 \mathrm{x}^{3}-4.939 \mathrm{x}^{2}+343.6 \mathrm{x}-7692$ & 0.69 \\
\hline $30 \mathrm{~cm}$ & $\mathrm{Y}=0.031 \mathrm{x}^{3}-6.754 \mathrm{x}^{2}+472.3 \mathrm{x}-10728$ & 0.60 \\
\hline $2013-14$ & & \\
\hline $15 \mathrm{~cm}$ & $\mathrm{y}=0.000 \mathrm{x}^{3}-0.082 \mathrm{x}^{2}+5.299 \mathrm{x}+1.968$ & 0.79 \\
\hline $22.5 \mathrm{~cm}$ & $\mathrm{Y}=0.000 \mathrm{x}^{3}-0.107 \mathrm{x}^{2}+6.722 \mathrm{x}-28.34$ & 0.73 \\
\hline $30 \mathrm{~cm}$ & $\mathrm{Y}=0.000 \mathrm{x}^{3}-0.100 \mathrm{x}^{2}+6.422 \mathrm{x}-30.61$ & 0.77 \\
\hline
\end{tabular}

Table.5 Relationship between stripe rust disease severity (Y) and HTR (pooled data 2012-13 and 2013-14)

\begin{tabular}{|l|l|l|}
\hline & \multicolumn{1}{|c|}{ Regression Equation } & $\mathrm{R}^{2}$ \\
\hline PBW 550 & & \\
\hline $15 \mathrm{~cm}$ & $\mathrm{Y}=2.591 \mathrm{x}^{2}-49.10 \mathrm{x}+224.8$ & 0.86 \\
\hline $22.5 \mathrm{~cm}$ & $\mathrm{Y}=2.731 \mathrm{x}^{2}-50.10 \mathrm{x}+220.1$ & 0.90 \\
\hline $30 \mathrm{~cm}$ & $\mathrm{Y}=2.696 \mathrm{x}^{2}-48.65 \mathrm{x}+208.1$ & 0.92 \\
\hline PBW 343 & & \\
\hline $15 \mathrm{~cm}$ & $\mathrm{Y}=2.375 \mathrm{x}^{2}-46.03 \mathrm{x}+218.0$ & 0.87 \\
\hline $22.5 \mathrm{~cm}$ & $\mathrm{Y}=2.534 \mathrm{x}^{2}-48.03 \mathrm{x}+221.0$ & 0.89 \\
\hline $30 \mathrm{~cm}$ & $\mathrm{Y}=2.615-48.15 \mathrm{X}+212.9$ & 0.91 \\
\hline
\end{tabular}

Table.6 Relationship between stripe rust disease severity (Y) and SHTR (pooled data 2012-13 and 2013-14)

\begin{tabular}{|l|l|c|}
\hline & \multicolumn{1}{|c|}{ Regression Equation } & $R^{2}$ \\
\hline PBW 550 & & \\
\hline $15 \mathrm{~cm}$ & $Y=4.552 \mathrm{x}^{2}-63.15 \mathrm{x}+209.6$ & 0.89 \\
\hline $22.5 \mathrm{~cm}$ & $\mathrm{Y}=3.460 \mathrm{x}^{2}-51.71 \mathrm{x}+189.4$ & 0.85 \\
\hline $30 \mathrm{~cm}$ & $\mathrm{Y}=5.000 \mathrm{x}^{2}-66.58 \mathrm{x}+208.7$ & 0.81 \\
\hline PBW 343 & & \\
\hline $15 \mathrm{~cm}$ & $\mathrm{Y}=-0.275 \mathrm{x}^{2}-19.59 \mathrm{x}+117.4$ & 0.93 \\
\hline $22.5 \mathrm{~cm}$ & $\mathrm{Y}=0.118 \mathrm{x}^{2}-24.01 \mathrm{x}+120.1$ & 0.92 \\
\hline $30 \mathrm{~cm}$ & $\mathrm{Y}=-0.608 \mathrm{x}^{2}-17.06 \mathrm{x}+105.3$ & 0.90 \\
\hline
\end{tabular}


Fig.1 Stripe rust severity in PBW 550 during 2012-13 crop season

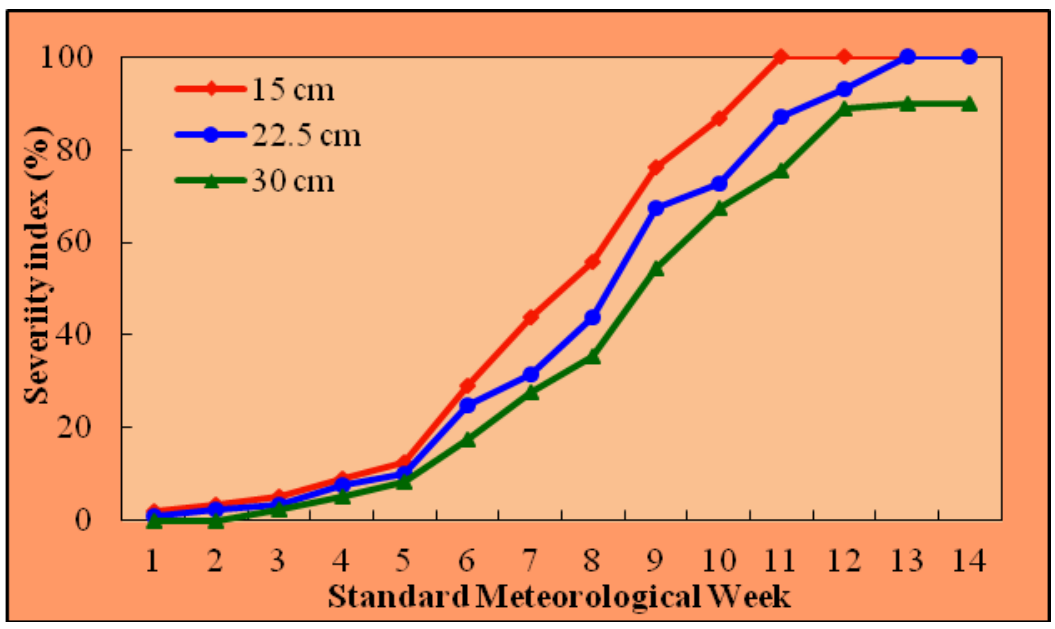

Fig.2 Stripe rust severity in PBW 343 during 2012-13 crop season

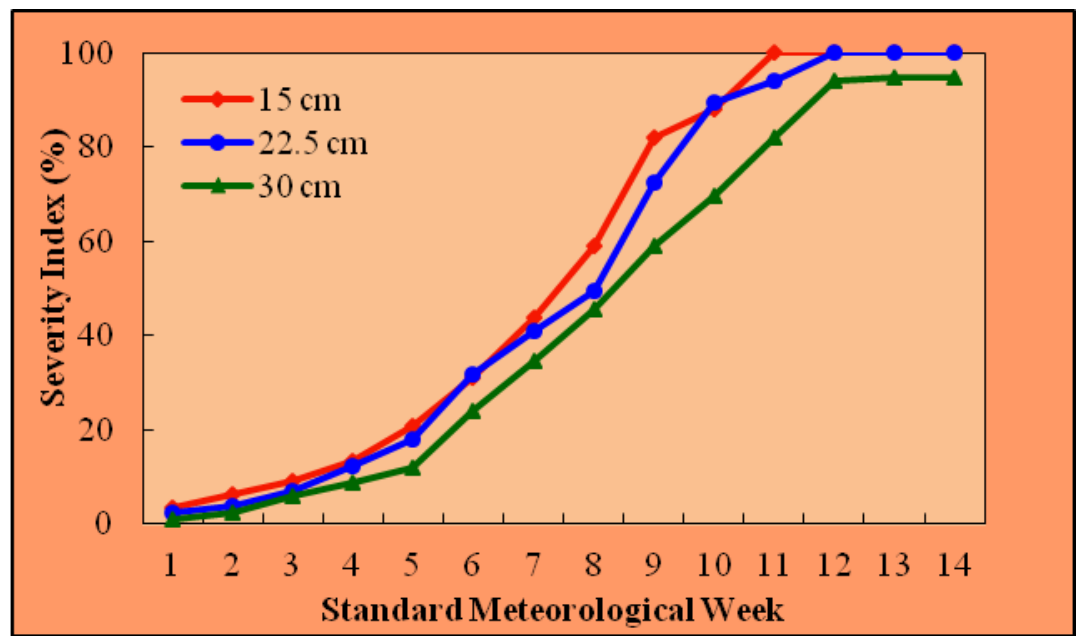

Fig.3 Stripe rust severity in PBW 550 during 2013-14 crop season

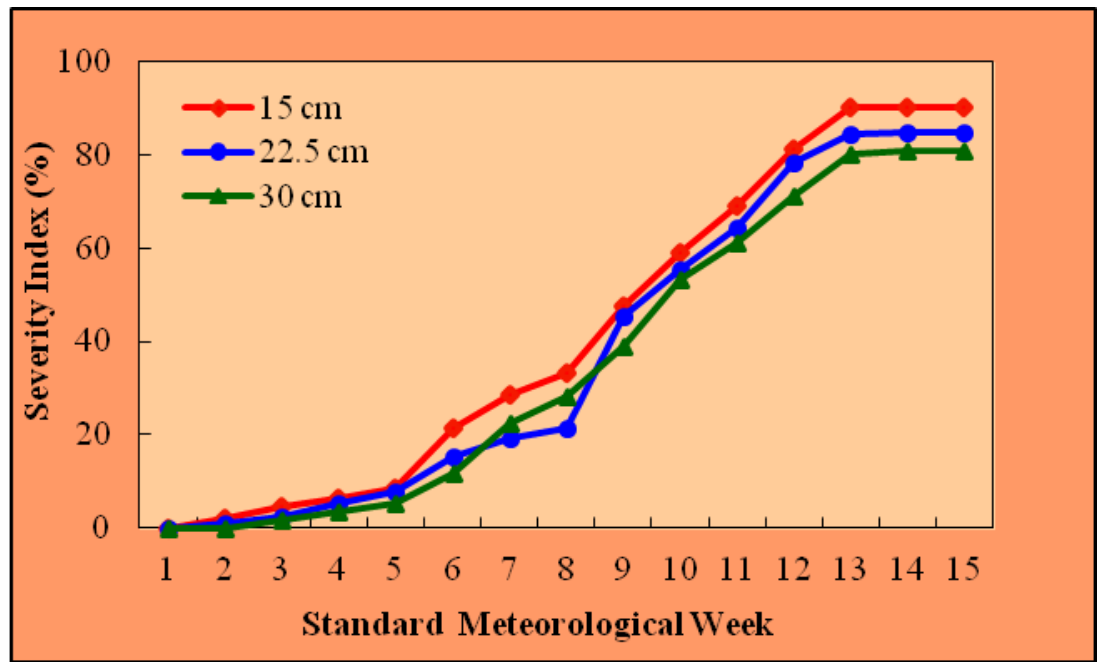


Fig.4 Stripe rust severity in PBW 343 during 2013-14 crop season

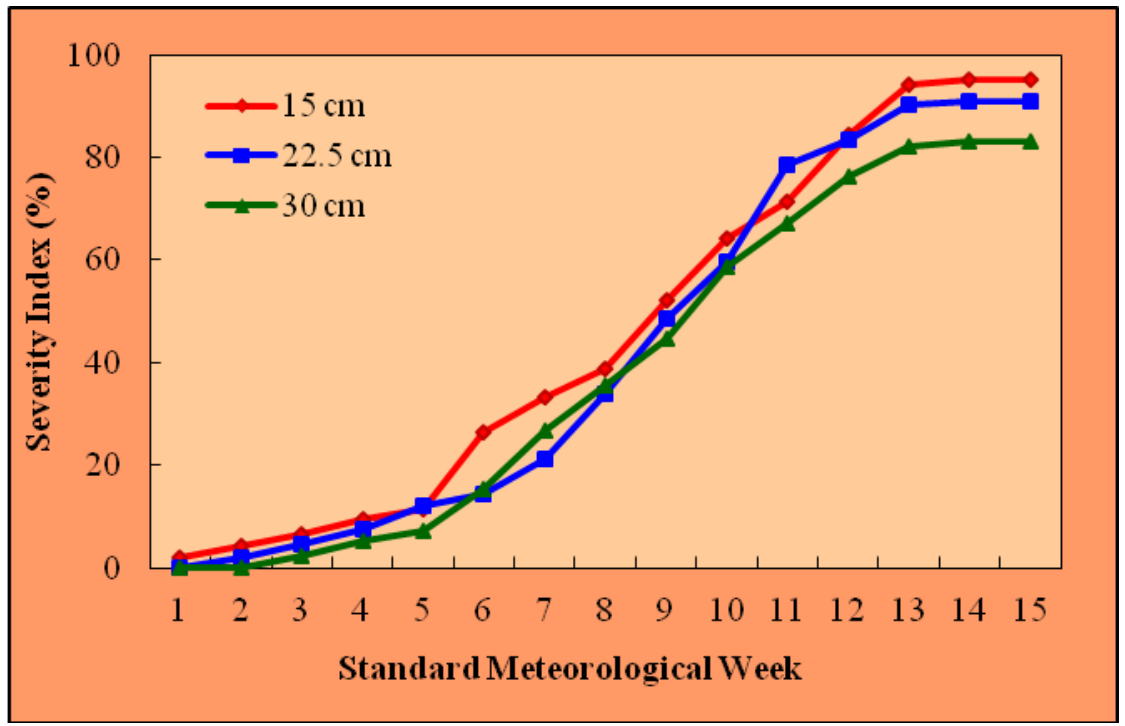

Fig.5 Comparison of Rainfall and stripe rust severity during 2012-13 and 2013-14 crop seasons

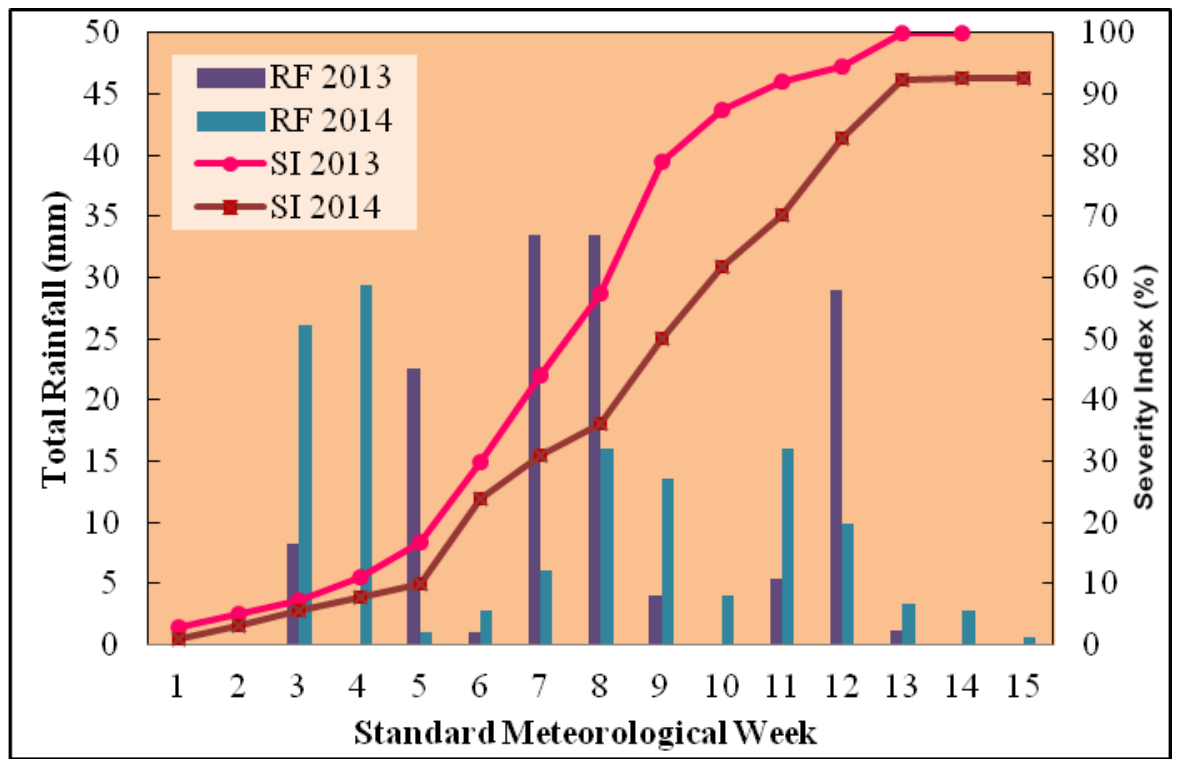

Disease severity and micrometeorological parameters

Microclimate plays an important role in disease development and multiplication. Canopy temperature was found low in narrow spacing $(15 \mathrm{~cm})$ during the early period of disease development but with the advancement in disease canopy temperature was highest in narrow spacing and lowest in wider spacing $(30 \mathrm{~cm})$. The main reason behind this change was development of stripe rust pustules on leaves of crop which lead to decrease rate of transpiration in narrow spacing crop and resulted in higher canopy temperature in narrow spacing as compared to wider spacing. Duveiller et al., 2005 concluded that canopy temperature is one of the factors associated with increased infection and disease development caused by $B$. sorokiniana. 
The maintenance of healthy tissues by plants enables them to maintain a lower canopy temperature which, in turn, helps against the pathogen which requires relatively high temperatures for faster growth and development. Relative humidity was highest in $15 \mathrm{~cm}$ sowing followed by $22.5 \mathrm{~cm}$ and was lowest in $30 \mathrm{~cm}$ sown crop but with advancement in disease relative humidity was decreased in narrow spacing as compared to wider spacing due to necrosis of leaves caused by stripe rust. Higher relative humidity was more favourable for disease development. These observations indicated that microclimate and disease are interrelated as disease was influenced by microclimate during early stage of disease development but once the disease was developed it influenced microclimate of crop.

Relationships were developed between disease severity and microclimatic parameters viz. canopy temperature and relative humidity within crop canopy as shown in tables 3 and 4. Higher $\mathrm{R}^{2}$-values in different treatments indicated that canopy temperature and relative humidity within crop influenced disease severity during both the crop seasons. From this analysis it is clear that wider spacing can be helpful to decrease the rate of disease severity in highly susceptible areas.

\section{Humid thermal ratio and disease severity}

Disease prediction is of fundamental importance for the successful and efficient use of chemicals to manage rusts. As weather factors are driving forces in plant disease development, they are essential in plant disease prediction, including the effect of weather on different parts of the disease cycle - dormancy, reproduction, dispersal and pathogenesis (De Wolf and Isard, 2007). Several rust disease prediction models (mostly empirical models) have been developed using weather variables alone
(Subba Rao et al., 1990, Eversmeyer and Kramer 1998) or in combinations with other biological parameters (Audsley et al., 2005).

Temperature and relative humidity have been identified as important predictor variables in a number of leaf rust prediction models. Similarly in this study analysis of multiple correlation coefficient showed that temperature and humidity gave significant value of multiple correlation coefficient. So humid thermal ratio (HTR) was calculated for different treatments and relationships were developed between HTR and disease severity as shown in table 5. As microclimatic parameters viz. canopy temperature and relative humidity within crop canopy showed interactions with disease severity so special humid thermal ratio (SHTR) was calculated by using canopy temperature and relative humidity within crop canopy. Relationships were developed between SHTR and disease severity as shown in table 6. Polynomial equations were found to be best fit and gave higher $\mathrm{R}^{2}$-value. If data of temperature and relative humidity is available for a region HTR can be used as a disease predictor variable. Similarly, Kumar (2014) also developed relationship between leaf rust and meteorological parameters and found that the correlation coefficients were highest for the Humid Thermal Ratio (HTR), Maximum Temperature (MXT) and Special Humid Thermal Ratio (SHTR), and these three weather variables were selected as predictor variables.

\section{References}

Audsley, E., Milne, A. and Audsley, N. 2005. A foliar disease model for use in wheat disease management decision support systems. Annals of Applied Biology.147: 161-72.

De Wolf, E.D. and Isard, S.A. 2007. Disease cycle approach to plant disease prediction. Annu. Rev. Phytopathol. 45:203-20. 
Duveiller E., Kandel Y.R., Sharma R.C. and Shrestha S.M. 2005.Epidemiology of foliar blights (spot blotch and tan spot) of wheat in the plains bordering the Himalayas. Phytopathol. 95: 248-256.

Dutta, Indrani, Dhaliwal, L. K., Mann, S. K. and Chahal S. K. 2008. Effect of meteorological parameters on phenology, yield and yield contributing characteristics and yellow rust of wheat.J.Agrometeorol. 10 (1): 189-92.

Eversmeyer, M. G., and Kramer, C. L. 1995. Survival of Puccinia recondita and $\mathrm{P}$. Graminis urediniospores exposed to temperatures from subfreezing to $35^{\circ} \mathrm{C}$. Phytopath.85:161-164.

Huerta-Espino, J., Singh, R. P., Germán, S., McCallum B. D., Park, R. F. and Chen, W. Q. 2011.Global status of wheat leaf rust caused by Puccinia triticina. Euphytica 179: 143-60.

Lemaire, D., Huret, S., Calaym F and Maraite, H. 2002. Understanding $P$. striiformis west. Epidemics on winter wheat. Meded Rijksuniv Gent -Fak Landlbourwkd Toegep. Biol Wet 67: 251-56.

Kumar, V.P.2014. Development of weather-based prediction models for leaf rust in wheat in the Indo-Gangetic plains of India. Eur $J$ Plant Pathol. 140:429-40.

Marchetti, M.A., Melching, J.S. and Bromfield, K.R.1976. The effects of temperature and dew period on germination and infection by urediospores of Phakopsora pachyrhizi. Phytopathol.66:461-63.

Milus, E.A., and Seyran, E. 2004. New races of Puccinia striiformis f. sp. tritici more aggressive than older races at $18{ }^{\circ} \mathrm{C}$. In Proceedings of the 11th International Cereal
Rusts and Powdery Mildews Conference. 22-27 August 2004, John Innes Centre, Norwich, UK. European and Mediterranean Cereal Rust Foundation, Wageningen, Netherlands. Cereal Rusts and Powdery Mildews Bulletin, Abstr. A2.50.

Murray, G. C.Wellings and Simpfendorfer, S.2005. Stripe Rust: Understanding the disease in wheat, New South Wales Department of Primary Industries. Pp 1-12.

Papastamati, K. Bosch. And Van den, F.2007.The sensitivity of the epidemic growth rate to weather variables, with an application to yellow rust on wheat. Phytopath 97: 2, 20210.

Peterson, R. E., Campbell, A. B., and Hannah, A. E.1948.A diagrammatic scale for estimating rust intensity of leaves and stems of cereals. Can J of Res. 26: 496-500.

Pielaat, A., Madden, L. V. and Gort, G.1998. Spores splashing under different environmental conditions: A Modeling Approach. Phytopath.88: 1131-39

Rader, T., Racca, P., Jorg, E.,and Hau, B. 2007. PUCREC/PUCTRIa decision support system for the control of leaf rust of winter wheat and winter rye. EPPO Bulletin, 37(2): 378-82.

Srinivasan, G.1983. Role of meteorological factors in the Epidemiology of Karnal bunt and rust diseases of wheat. M.Sc Thesis, Punjab Agricultural University, Ludhiana.

Subba Rao, K. V., Berggren, G. T. and Snow, J. P. 1990.Characterization of wheat leaf rust epidemics in Louisiana. Phytopath. 80: 402-10.

\section{How to cite this article:}

Sarabjot Kaur Sandhu, L.K. Dhaliwal and Pannu, P.P.S. 2017. Effect of Meteorological and Micrometeorological Parameters on Stripe Rust (Puccinia striformis f. sp. tritici) Severity of Wheat. Int.J.Curr.Microbiol.App.Sci. 6(7): 4512-4520.

doi: https://doi.org/10.20546/ijcmas.2017.607.470 